\title{
慢性関節リウマチ患者の家系調査
}

国立福岡中央病院整形外科

首 藤 敏 秀・近 藤 正 一
三 浦 裕 正・河 田 典 久
横 山 庫一郎・篠 原 典 夫
宮崎県立宮崎病院整形外科

長 嶺 隆 二

\section{Epidemiological and Genetic Aspects of Family Study in Rheumatoid Arthritis} by

Toshihide Shuto, Masakazu Kondo, Hiromasa Miura, Norihisa Kawada, Koichiro Yokoyama and Norio Shinohara

Department of Orthopedic Surgery,

National Fukuoka Central Hospital, Fukuoka, Japan

Ryuji Nagamine

Department of Orthopedic Surgery, Miyazaki Prefectural Hospital, Miyazaki, Japan

The etiology of rheumatoid arthritis has not been fully understood. Genetic factors have been pointed out to be involved in pathogenesis of RA because of many clinical and experimental facts. In this report, first we studied intrafamiliar accumulation of RA by the questionaire for $314 \mathrm{RA}$ patients receiving treatment in our hospital. Patients with intrafamiliar accumulation were found in the frequency of 22 percent of all, and these patients tend to show onset at younger age than patients without intrafamiliar accumulation.

HLA typing was performed for 17 RA patients whose parents or children suffered from RA. 13 patients $(76.5 \%)$ of them have HLA-DR4 antigen.

$$
\text { 目的 }
$$

慢性関節リウマチ（以下 RA と略す）の発症に関与 する宿主因子の一つとして，従来より遺伝要因が示唆 されてきた. 今回，われわれは，RA 患者の家系調査を 行い, 家族歴を有する RA 患者の頻度, 発症年令, HLA との相関などについて調査した。

\section{対象および方法}

当科にて加療中の classical および definite RA 患者 314 例に対しアンケートによる家系調查を実施した(表 1).さらにアンケート調查の結果, 一親等に RA 発症 患者を有する患者のうち 17 例に対し, HLA タイピン
グを実施した。また，ステロイド使用の有無や，病期 の進行度, リウマチ因子の有無と HLA の相関に関して も検討を加えた。

結果

アンケート総数 314 例のうち, 回答数が 263 例 (83.8

\%), そのうち「RA の家族歴あり」とする者が 72 例 $(27.3$

\%)であった.さらにそのうち「一親等に RA 患者あり」

とする者が 26 例 $(9.8 \%)$, 「二親等に RA 患者あり」 とする者が 15 例 $(5.7 \%)$ ，「三親等以上」では 31 例 (11.8\%)であった（図 1 ).

また，これら家族歴のある RA 患者と家族歴のない RA 患者の発症年令を比較すると前者の方が後者より低 
表 1 〈アンケート調査用紙〉

1）いつ慢性関節リウマチが発症しましたか だいたいでよろしいですのでお答え下さい

1. 20才以下 2. 20才台 3. 30才台

4. 40才台 5. 50才台 6. 60才以上

2）ご家族や親戚に慢性関節リウマチの方がいらっしゃいますか

1. いる 2 . いない

3）2）で1. と回答された方にお聞きします. その方はあなたとどの様な関係の方ですか
1. 母親
2. 父親
3. 姉または妹
5. 息子
6. 娘
7. 祖父
9. 従兄弟
10. 伯父伯母
11. 叔父叔母
4. 兄または弟
8. 祖母
12. その他

氏名

年令

性別

アンケート総数 314 例

回答 数 263 例 $(83.8 \%)$

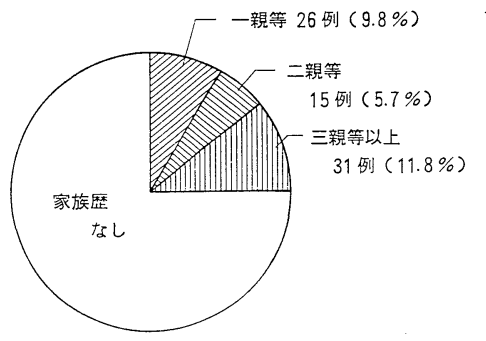

家族歷あり

72 例 $(27.3 \%)$

図 1 アンケート調查結果

い傾向が認められた（図 2 ）。

アンケート調査の結果,「一親等に RA 患者あり」と 回答した 26 例のうち 21 例 $(80.8 \%)$ に詳しい問診をす ることができた。その際家族内の RA 患者を直接検診 したかったのであるが，そのほとんどはすでに死亡し ていた。そこで詳細な問診の結果，21 例中 17 例(80.9 \%)の家族は, 実際に医師により RA の診断を受けたか, あるいは RA の診断基準を満たす可能性が大きいと判 断した。

そこで，患者の言う RA の診断に対する信頼度を， 前の結果よりおよそ $80 \%$ と仮定し,さきほどのアンケ 一ト調查結果を補正すると,「家族歴あり」の患者は 22.0 $\%$ ，そのうち「一親等に家族歴あり」では $7.9 \%$ あ った(図 3 ).

さらに,「一親等に家族歴あり」とする RA 患者 17 例 に対し HLA タイピングを実施した. その結果, RA と 正の相関を示すといわれる Bw 54, Bw 59, DR 4, DRw $53^{1) \sim 410)}$ のうち DR4 陽性例が 13 例 (76.5\%) と高率に 認められた.また RA と負の相関を示すといわれる DR 2 は 3 例 $(17.6 \%)$, と陽性例が少ない傾向が認められ た. 金やD-ペニシラミン療法時の副作用と正の相関が

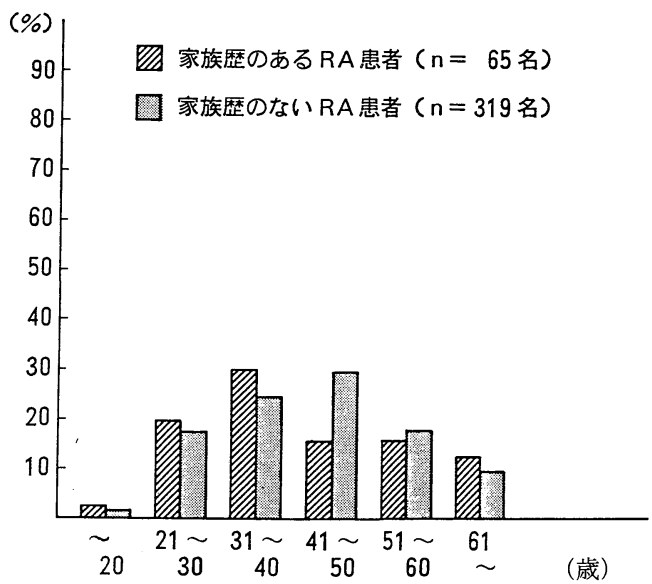

図 2 R A の発症年歯

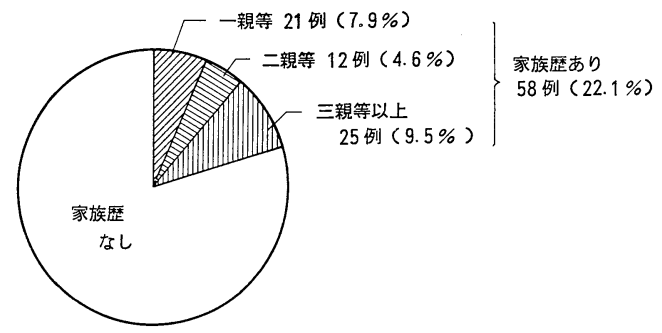

図 3 家族歴を有する患者の割合

（患者の信頼度を $80 \%$ として補正）

あるといわれる DR3 $3^{5) 6)}$ は 1 例もなかった.

次に, 先ほどの 17 例の HLA-A, B, C locus それぞ れのタイプの陽性率を日本人の一般対照 ${ }^{7}$ のそれと比較 した.その結果, DR 4 の陽性率は対照に比べ有意に高 く $(\mathrm{p}<0.01)$ また, 相対危険率は 4.89 だった. DR4 以 外は調査症例数が少なかったためか, 対照に比べ統計 学的に有意な差は認められなかったが, Bw 59 に関し 

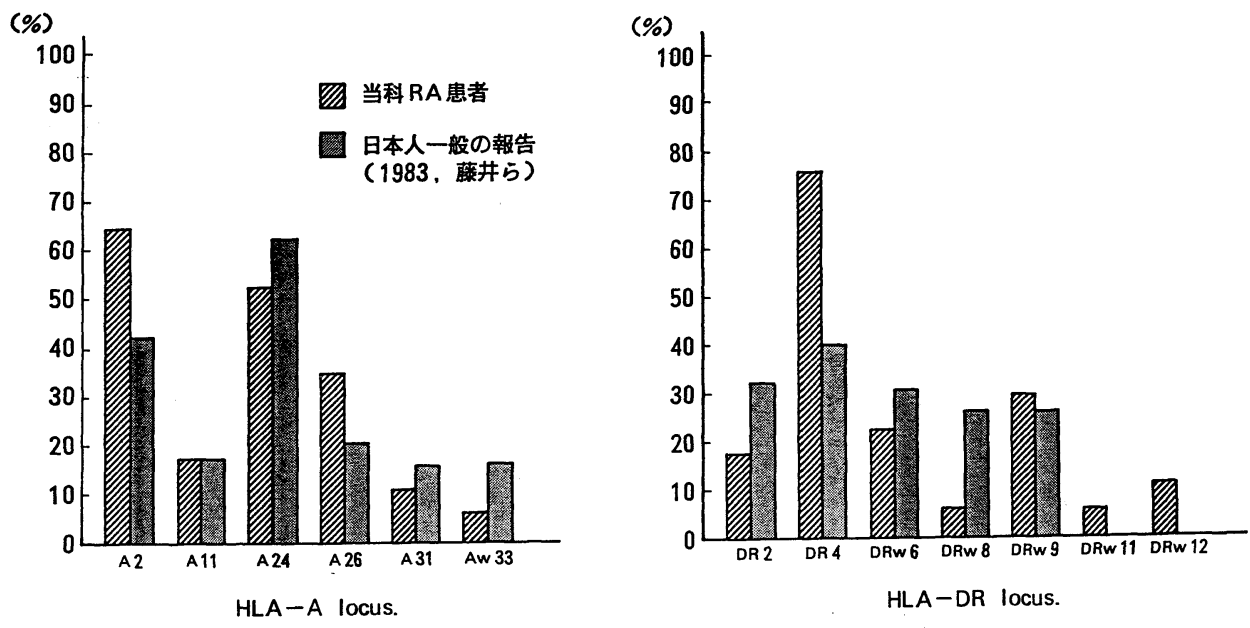

図 4 HLA タイプの陽性率 (A, DR locus.)

(\%)

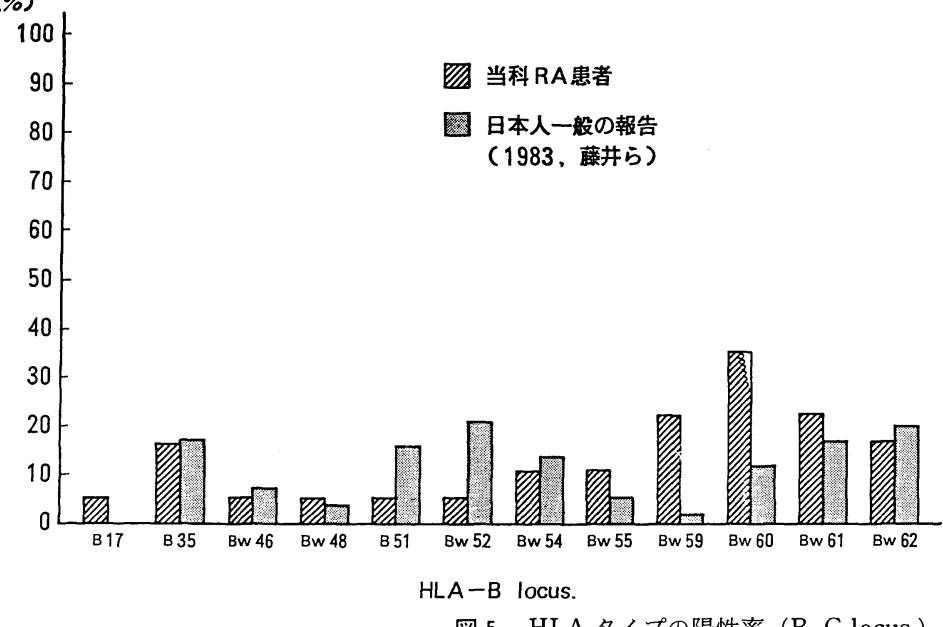

(\%)

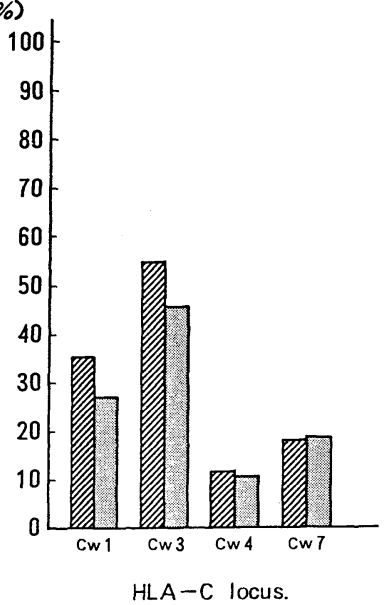

表 2 RA 患者17名の主な HLA タイプの陽性率

\begin{tabular}{lrll}
\hline \hline Bw 54 & $2 / 17$ & $(11.8 \%)$ & (R. R. $=0.79)$ \\
Bw 59 & $4 / 17$ & $(23.5 \%)$ & (R. R. $=7.0)$ \\
DR 2 & $3 / 17$ & $(17.6 \%)$ & \\
DR 4 & $13 / 17$ & $(76.5 \%)$ & (R. R. $=4.89)$ \\
DR 3 & $0 / 17(0$ & $(0 \%)$ & \\
DRw 53 & $0 / 17$ & $(0 \%)$ & \\
\hline
\end{tabular}

ては相対危険率が 7.0 と高かった（図 4，5，表 2 ）。

また，ステロイド使用の有無や病期の進行度，リウ マチ因子の有無に関し,DR 4 およびDR 2 の陽性また は陰性の頻度を比較したが，相関関係は認められなか った (表 3 ).

考

察

一般に，ある疾患の家系調查をする場合，その疾患 の診断根拠が確実なものでなければならないが, RAに おいてはその疾患自体異質なものを含んでいる可能性 もある。このことが RA の正確な疫学調査を困難にし ている. 同一家系に RA が多発することは以前から知 られている ${ }^{8)}$.また本邦でも家族内に RA 患者のいるも のは 275 例中 36 例 $\left(13.1 \%\right.$ ) という報告がある ${ }^{9}$.

今回の調査では，家族の直接検診ができなかったた めに RA という診断の確かさという点でやや正確性に かける可能性はあるが, 危険率を考慮しても，「家族歷 あり」が $22.0 \%$ ，そのうち「一親等にRA 患者あり」 
表 3 RA の臨床像と HLA-DR4, DR2 の相関

\begin{tabular}{|c|c|c|c|c|}
\hline & DR $4(+)$ & DR $4(-)$ & DR $2(+)$ & DR $2(-)$ \\
\hline $\begin{array}{l}\text { 使用群 } \\
\text { 非使用群 }\end{array}$ & $\begin{array}{ll}9 / 11 & (81 \%) \\
4 / 6 & (67 \%)\end{array}$ & $\begin{array}{ll}2 / 11 & (19 \%) \\
2 / 6 & (33 \%)\end{array}$ & $\begin{array}{ll}2 / 11 & (19 \%) \\
1 / 6 & (17 \%)\end{array}$ & $\begin{array}{ll}9 / 11 & (81 \%) \\
5 / 6 & (83 \%)\end{array}$ \\
\hline $\begin{array}{c}\text { Stage III, IV群 } \\
\text { 川 I, II群 }\end{array}$ & $\begin{array}{cc}10 / 14 & (71 \%) \\
3 / 3 & (100 \%)\end{array}$ & $\begin{array}{ll}4 / 14 & (29 \%) \\
0 / 3 & (0 \%)\end{array}$ & $\begin{array}{l}(21 \%) \\
(0 \%)\end{array}$ & $\begin{array}{cc}11 / 14 & (79 \%) \\
3 / 3 & (100 \%)\end{array}$ \\
\hline $\begin{array}{l}\text { RA test (+) 群 } \\
\begin{array}{l}\|(-) \text { 群 }\end{array}\end{array}$ & $\begin{array}{cc}10 / 14 & (71 \%) \\
3 / 3 & (100 \%)\end{array}$ & $\begin{array}{ll}4 / 14 & (29 \%) \\
0 / 3 & (0 \%)\end{array}$ & $\begin{array}{ll}3 / 14 & (21 \%) \\
0 / 3 & (0 \%)\end{array}$ & $\begin{array}{lr}11 / 14 & (79 \%) \\
3 / 3 & (100 \%)\end{array}$ \\
\hline
\end{tabular}

が $7.9 \%$ とかなりの家族発症が認められている。同一 家系の構成員は, 確かに生活習慣, 栄養状態, 感染へ の暴露などで共通点をもつと思われる。しかし，ほぼ 同一の環境を有し，かつ遺伝的構成の異なる配偶者に RA の発症が多いという報告はなく,また明らかになん らかの感染を思わせるような患者の多発があったとい う報告もない，したがって，やはり同一家系に RA が 多発していることは, RA 発症に遺伝要因が関与してい ることを強く疑わせる所見であると考えられる。

過去の報告によると, RA では表 1 のごとく, 一般対 照に比べ, Bw 54, Bw 59, DR 4, DRw 53, などの陽 性率が高く, 逆にDR 2 の陽性率は低くなるといわれ ている. 今回の調査では, DR 4 のみ強い正の相関関係 が認められた. また重症なものほどDR 4 と強い正の 相関関係を示すとする報告や, リウマチ因子陽性例は 陰性例に比べDR 4 陽性率が高いとする報告があるが, 今回の調査ではそれらの相関関係は認められなかった。

$$
\text { ま と め }
$$

当科加療中の RA 患者 314 例に対し, 家系調査を行 った. その結果，家族歴を有する患者が全体の $22.0 \%$ と高頻度に認められ，これらの患者では家族歴のない 患者に比べ発症年令が低い傾向が認められた。 また， 一親等に家族歴を有する RA 患者に $76.5 \%$ 高率で HLA-DR4 陽性例が認められ, 相対危険率は, 4.89 だ った.これらのことより RA 発症になんらかの遺伝要 因が強く関与していることが示唆された.
(本調査は, 平成元年度難病の疫学調査研究班の研究 費によって行いました。)

\section{参 考 文 献}

1) Stastney, P.: Mixed lymphocyte culture in rheumatoid arthritis. J. Clin. Invest. 57 : 1148-1157, 1976.

2) Stastney, P.: Association of the B-cell alloantigen DRw4 with rheumatoid arthritis. N. Engl. J. Med. 298: 869-871, 1978.

3)' Sasazuki, T. et al : HLA-linked genes controlling immune response and disease susceptibility. Immunol. Rev. 70 : 50-75, 1983.

4) Ohta, N. et al: Association between HLA and Japanese patients with rheumatiod arthritis. Human Immunol. 5 : 123-132, 1982.

5) Panayi ; , G. S. et al : Genetic basis of rheumatoid disease manifestation and toxic reactions to drugs. Br. Med. J., 2 : 1326-1328, 1978.

6) Wooley, P., et al: HLA-DR antigens and toxic reaction to sodium aurotiomaiate and $\mathrm{D}$ penicillamine. N. Eng. Med., 303 : 300-302, 1980.

7）徳永勝士・他：日本人のHLA分布. 日本臨床. 42 ： 335-344, 1984.

8) Alarcon GS, Koopman WJ, Acton TR, Bargen BO.: Seronegative rheumatoid arthritis; a immunogenetic disease? Arthritis Rheum, 25 : 502-507, 1982.

9）延永正，鳥巣岳彦：慢性関節リウマチの診療. p - 7. 東京, 宇宙堂. 1981 .

10）脇坂明美: 難病と HLA, 日本の現況. 臨床免疫. $14: 2,1982$. 